\title{
On Munduruku, a new Theraphosid genus from Oriental Amazonia (Araneae, Mygalomorphae)
}

\author{
Laura T. Miglio ${ }^{1}$, Alexandre B. Bonaldo ${ }^{1} \&$ Fernando Pérez-Miles $^{2}$ \\ 1. Laboratório de Aracnologia, Museu Paraense Emílio Goeldi, Caixa Postal 399, 66017-970 Belém, Pará, Brazil. (lauramiglio@gmail.com; bonaldo@museu-goeldi.br) \\ 2. Sección Entomología, Facultad de Ciencias, Iguá 4225, 11400 Montevideo, Uruguay. (myga@fcien.edu.uy)
}

ABSTRACT. Munduruku gen. nov. is proposed for the type species Munduruku bicoloratum sp. nov., from Juruti and Santarém, Pará, Brazil. The main diagnostic character of Munduruku gen. nov. is the presence of a subapical, lanceolate keel on the male palpal bulb, which is unique among the basal taxa of Theraphosinae with type III-IV urticating setae. The female spermathecae consist of two spheroid receptacles with funnel-shaped necks, each of which bears a sclerotized area. In both sexes, the abdomen is remarkably patterned, an uncommon feature in adults of New World theraphosids. Both the bulbus lanceolate keel and the abdominal color pattern are hypothesized as synapomorphies of the genus.

KEYWORDS. Neotropics, tropics, Systematics, Taxonomy, spiders.

RESUMO. Sobre Munduruku, um novo gênero de Theraphosidae da Amazônia Oriental (Araneae, Mygalomorphae). Munduruku gen. nov., é proposto para a espécie-tipo Munduruku bicoloratum sp. nov., de Juruti, e Santarém, Pará, Brasil. O principal caráter diagnóstico de Munduruku gen. nov. é a presença de uma quilha subapical lancelotada no bulbo copulatório do macho, único no grupo basal de Theraphosinae com cerdas urticantes do tipo III-IV. A espermateca da fêmea consiste em dois recipientes esferóides com pescoço em forma de funil, cada um dos quais tendo uma área esclerotizada. Em ambos os sexos, o abdômen apresenta um padrão de colorido característico, o que é incomum em adultos de terafosídeos do Novo Mundo. Tanto a quilha lanceolada do bulbo quanto o padrão de colorido do abdômen são hipotetizados como sinapomorfias do gênero.

PALAVRAS-CHAVE. Neotrópico, trópico, sistemática, taxonomia, aranhas.

Theraphosidae harbors the largest spiders in the world and constitutes the most speciose family of the infraorder Mygalomorphae, with 946 species in 124 genera (PlatNICK, 2013). They are distributed mainly in the Neotropical, Ethiopian, Oriental and Australian regions, with a few species in southern Europe. About half of the known species inhabit the Neotropics, most of them included in the Theraphosinae, endemic to this region. Due to the homogeneity of theraphosinae morphology, and consequently the scarcity of taxonomic characters, great confusion has reigned in the classification of the group (Schiapelli \& Gerschman, 1979; Valerio, 1980; Minch, 1989; Raven, 1990; Pérez-Miles et al., 1996; Bertani, 2000; Perdomo et al., 2009). More recent scientific contributions improved the tools for species recognition, for cladistic studies, and also for taxa discovery. Among these contributions, BerTANI (2000) made an important study of homology of keels on male palpal bulb, which now constitute key features in Theraphosinae taxonomy. The presence of keels and an extended subtegulum on the male palpal bulb (RAVEN, 1985), together with theraphosinae urticating setae, were considered the main synapomorphies for the subfamily (PÉREZ-Miles et al., 1996).

A parcel of tarantula specimens, representing a single species, recently collected in the Oriental Amazonia (Pará, Brazil), share the synapomorphies of Theraphosinae, but did not fit any of the known genera. They have type III (males) and types III, IV (females) urticating setae, but differ from all basal Theraphosinae with these types of urticating setae by the presence of a lanceolate subapical keel on the male palpal bulb and by the presence of an unusual dorsal pattern on the abdomen, composed of a wide longitudinal dark brown band with several lateral extensions. These two characters are here considered as putative synapomorphies of an undescribed lineage. Consequently, we propose Munduruku gen. nov., which is diagnosed, described and figured on the basis of the type species, Munduruku bicoloratum sp. nov.

\section{MATERIAL AND METHODS}

Abbreviations: AME, anterior median eyes; ALE, anterior lateral eyes; PME, posterior median eyes; PLE, posterior lateral eyes; OQ, ocular quadrangle (including lateral eyes); d, dorsal; p, prolateral; r, retrolateral; v, ventral; MPEG, Museu Paraense Emílio Goeldi (Belém, Pará, Brazil). Male palpal bulb keel terminology follows BERTANI (2000): PSK, prolateral superior keel; PIK, prolateral inferior keel; SAK, subapical keel. All measurements are in millimeters $(\mathrm{mm})$ and were taken using an ocular micrometer. Drawings were made with the aid of a camera lucida. Urticating setae terminology follows COOKE et al. (1972).

\section{RESULTS AND DISCUSSION}

\section{Munduruku gen. nov.}

Type species: Munduruku bicoloratum sp. nov.

Etymology: Munduruku is a noun in apposition from the Munduruku (a language of the Tupi linguistic trunk) and is the name of an indigenous tribe which 
inhabited the region of Juruti, the typical locality of the type species of the genus; the gender is neuter.

Diagnosis. Differ from the majority of theraphosinae genera by the presence of type III (male) and III, IV (female) urticating setae and by the presence of a patterned abdomen (Figs 2-4); from Cyriocosmus Simon, 1903 and Hapalopus Ausserer, 1875, the only other theraphosinae genera with patterned abdomens, in the shape of the abdominal pattern and in the general morphology of the male palp and female spermathecae, especially the absence of a paraembolic apophysis on the male palp; from all genera with similar urticating setae patterns, by the presence of a SAK (Figs 6, 13) on the male palpal bulb. In addition to the presence of abdominal pattern and SAK, they also differ from Plesiopelma Pocock, 1901 in the absence of a basal process on the male metatarsus I and in the morphology of the double tibial apophysis, with fused bases and convergent branches (Figs 5, 14).

Affinities. Munduruku gen. nov. resembles Plesiopelma in the presence of type III and IV urticating hairs, and in the general pattern of male palpal organ morphology, but differs from that genus in the size and morphology of the palpal organ, which presents a distinct SAK (Figs 6, 13). In Plesiopelma, males have a small, subapical tooth which is an extension of the PIK, while in Munduruku gen. nov. this structure is a separate keel, as in Vitalius Lucas, Silva Junior \& Bertani, 1993 and Nhandu Lucas, 1981 (genera which lack type IV urticating setae, having types I and III instead). The new genus also differ from Plesiopelma in the absence of a basal process on the male metatarsus I and in the morphology of the male tibial apophysis on leg I (Figs $5,14)$. Also, the female spermathecal receptacles are not twisted. Females of Munduruku gen. nov. present spermathecae with two spheroid distal receptacles, with a straight funnel-shaped neck bearing a sclerotized area (Fig. 8). Males and females also differ from those of Plesiopelma species by the presence of a singularly shaped abdominal pattern (Figs 2-4). In this regard, Munduruku gen. nov. resembles Cyriocosmus and Hapalopus, but the pattern is different and our specimens do not belong to either of these genera, as indicated by several characters, including genital morphology in both sexes.

Given the absence of a phylogenetic framework for Theraphosinae, an alternative course of action would be to consider the species described below as an additional species of Plesiopelma. This would avoid the proposition of another monotypic genus in a complex
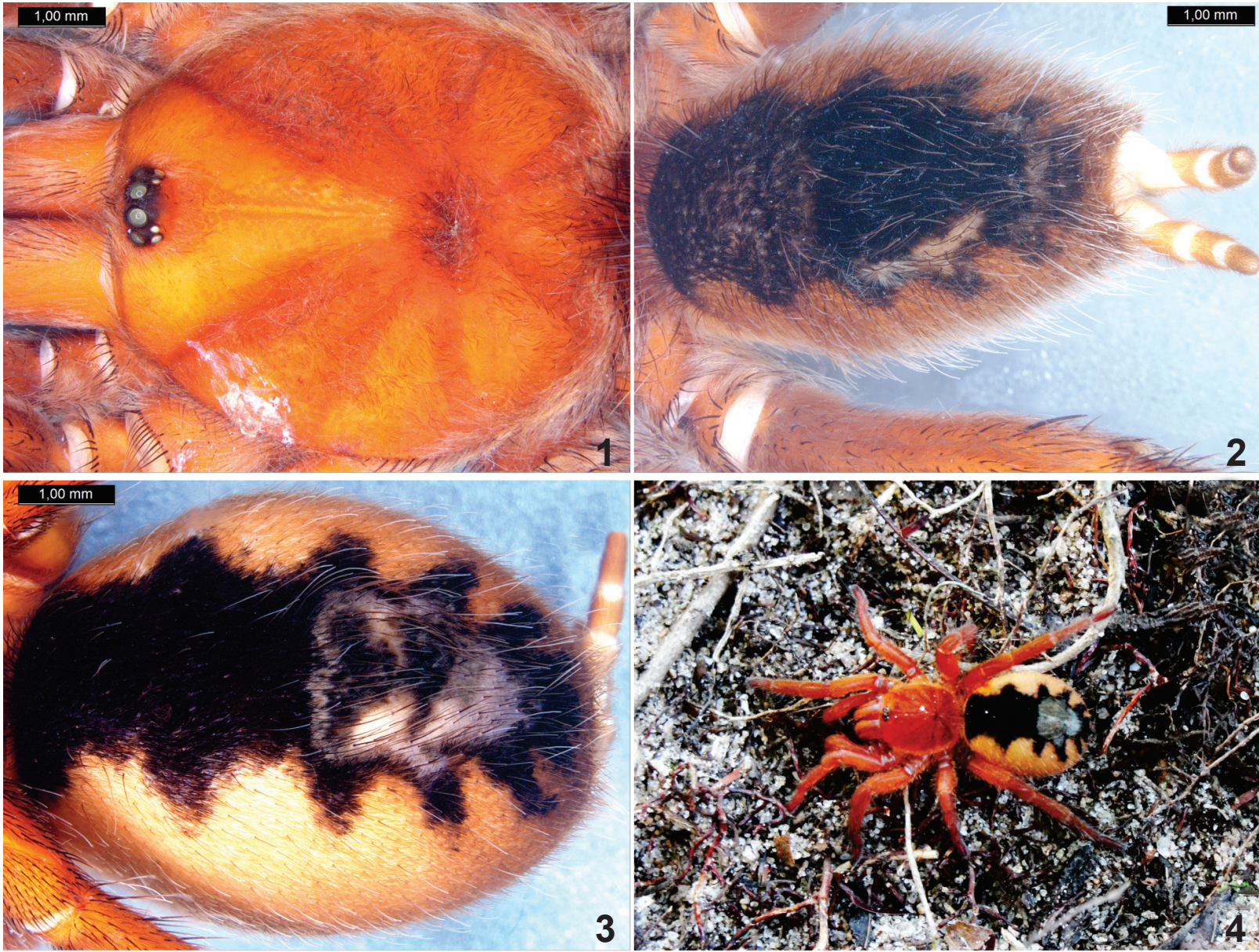

Figs 1-4. Munduruku bicoloratum gen. nov., sp. nov. Male holotype (MPEG 19026): 1, carapace, dorsal; 2, abdomen, dorsal; 3, female paratype (MPEG 19029): abdomen, dorsal; 4, juvenile: body, dorsal. 

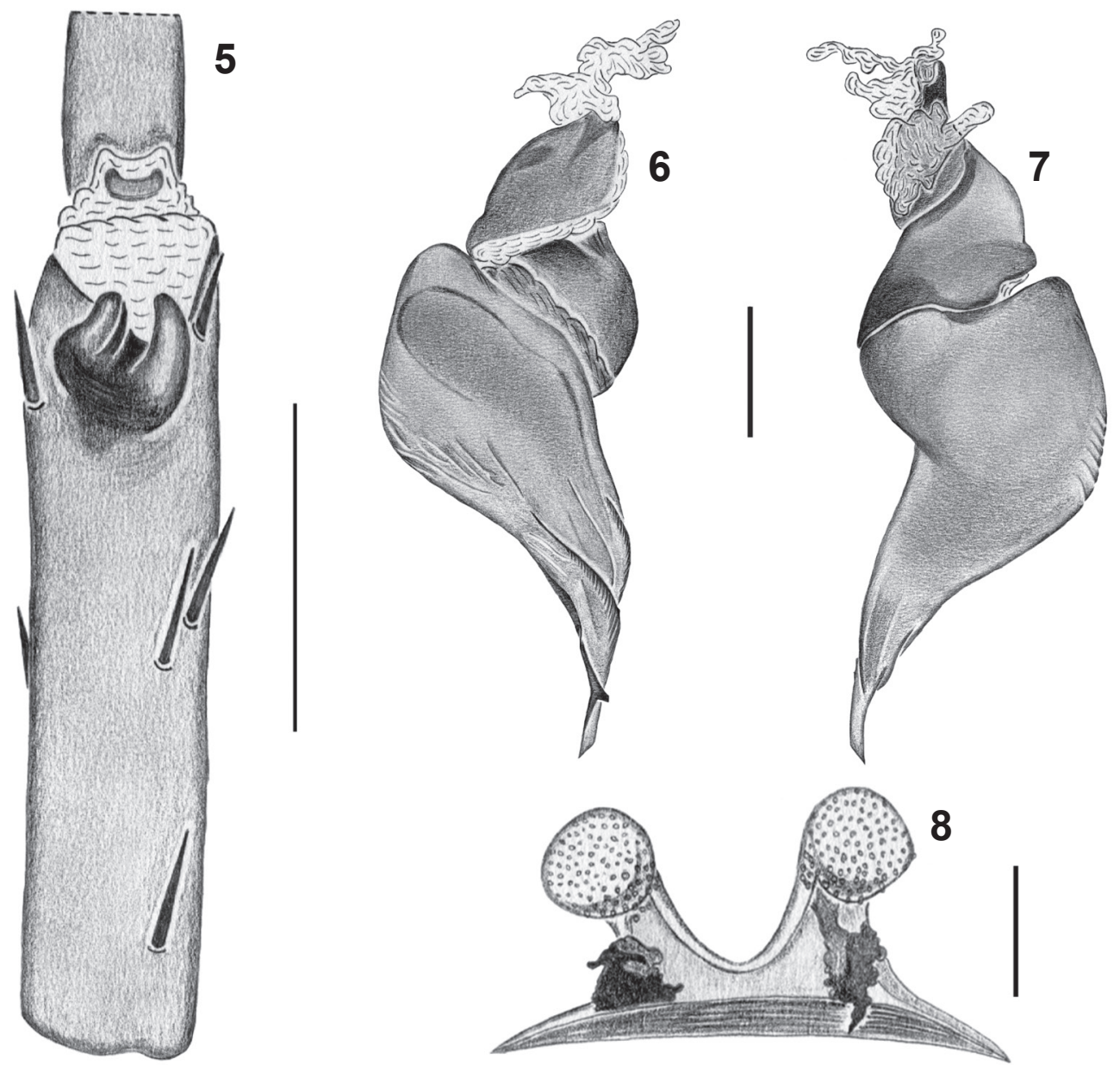

Figs 5-8. Munduruku bicoloratum gen. nov., sp. nov. Male holotype (MPEG 19026): 5, tibial apophysies, ventral; 6, 7, copulatory bulb prolateral and retrolateral, respectively. 8, female, paratype (MPEG 19029), spermathecae, dorsal. Scales: 5, $4 \mathrm{~mm} ; 6$ 6-7, $1 \mathrm{~mm} ; 8,2 \mathrm{~mm}$.

group of spiders which classification is already weak. However, the inclusion of Munduruku bicoloratum sp. nov. in Plesioplema would bring far more problems than solutions. From a strictly operational point of view, this decision would broaden the diagnosis of the genus to an unworkable level. From a phylogenetic point of view, including M. bicoloratum sp. nov. in Plesiopelma would probably turn this taxon into a non-monophyletic group, since the species here described do not share any of the characters presently considered as putative synapomorphies of Plesiopelma, such as the conspicuous metatarsal process. On the other hand, the unique combination of characters presented by Munduruku bicoloratum sp. nov., including two exclusive characters that may be regarded as potential synapomorphies, is strong evidence that this species belongs to a lineage of its on.

Description. See description of the type species.

\section{Munduruku bicoloratum Miglio, Bonaldo \& Pérez-Miles sp. nov.}

(Figs 1-14; Tab. I)

Type material. Holotype ふ̋, 01³6’44.7’S, 56¹1'39.2”W, Mutum, Acampamento Mutum, Juruti, Pará, Brazil, 06.VI.2007, H. F. da Silva Filho leg. (MPEG 19026). Paratypes: Brazil, Pará: Juruti, 01³6'44.7'S, 56¹1'39.2'O, Mutum, Acampamento Mutum,
9, 04.VI.2007, D. F. Candiani leg. (MPEG 19028); 02²7’455’S, $56^{\circ} 00^{\prime} 510^{\prime \prime O}$, Barroso, Sítio 3 Irmãos, + , 12.VIII.2008, N. C. Bastos leg. (MPEG 19029); 02³0’25.4”S, 56¹1'04.8'O, Capiranga, §’, 06.VI.2007, H. F. da Silva Filho leg. (MPEG 19027); platô Juruti, , II.2007, T. C. S. Ávila-Pires et al. (MPEG 19025); ferrovia, Km 26 da Ferrovia, đ, 09.V.2007, A. Lima, P. Suarez \& A. J. Baia Goes leg. (MPEG 19030); Santarém, 03¹0'16.6”S, 5548'57.8”O, RESEX Tapajós-Arapiuns, junto ao Rio Inambú, Comunidade Nova Canaã, §, 12-26.VI.2011, M. S. Hoogmoed \& T. C. S. Ávila-Pires leg. (MPEG 19031); ふै, ๆ, 12-26.VI.2011, M. S. Hoogmoed \& T. C. S. Ávila-Pires leg. (MPEG 19032). All type specimens are deposited in the arachnological collection of the Museu Paraense Emílio Goeldi (MPEG).

Etymology. The specific epithet is a Latin adjective refering to the two-colored abdomen, with a dorsal dark brown chevron contrasting with light brown lateral sides and venter.

Diagnosis. See the diagnosis of the genus.

Description. Male (holotype): total length (excluding chelicerae and spinnerets) 25.40, carapace length 12.20, width 10.90. Anterior eye row slightly procurved, posterior row recurved. Eyes sizes and interdistances: AME 0.45, ALE 0.38, PME 0.21, PLE 0.26, AME-AME 0.19, AME-ALE 0.19, PME-PME 0.92, PME-PLE 0.06, ALE-PLE 0.21, OQ length 1.09, width 1.84, clypeus 0.39 . Fovea transverse, procurved, width 1.13. Labium length 1.41 , width 1.88 , with 68 cuspules, 
maxillae with 243 cuspules. Sternum length 5.80, width 5.20. Posterior sigillae submarginal. Chelicerae with $12 / 12$ teeth on promargin, group of 30 smaller basal teeth behind promarginal line. Tarsi I-IV densely scopulate, scopula I-II entire (Figs 9, 10), III divided by narrow line of longer conical setae, IV divided by wide band of longer conical setae. Metatarsi I-III scopulate on distal $1 / 5$, IV not scopulate. Tibia I with prolateroventral, distal double apophysis with base fused, branches convergent, with megaspine on retrolateral branch (Figs
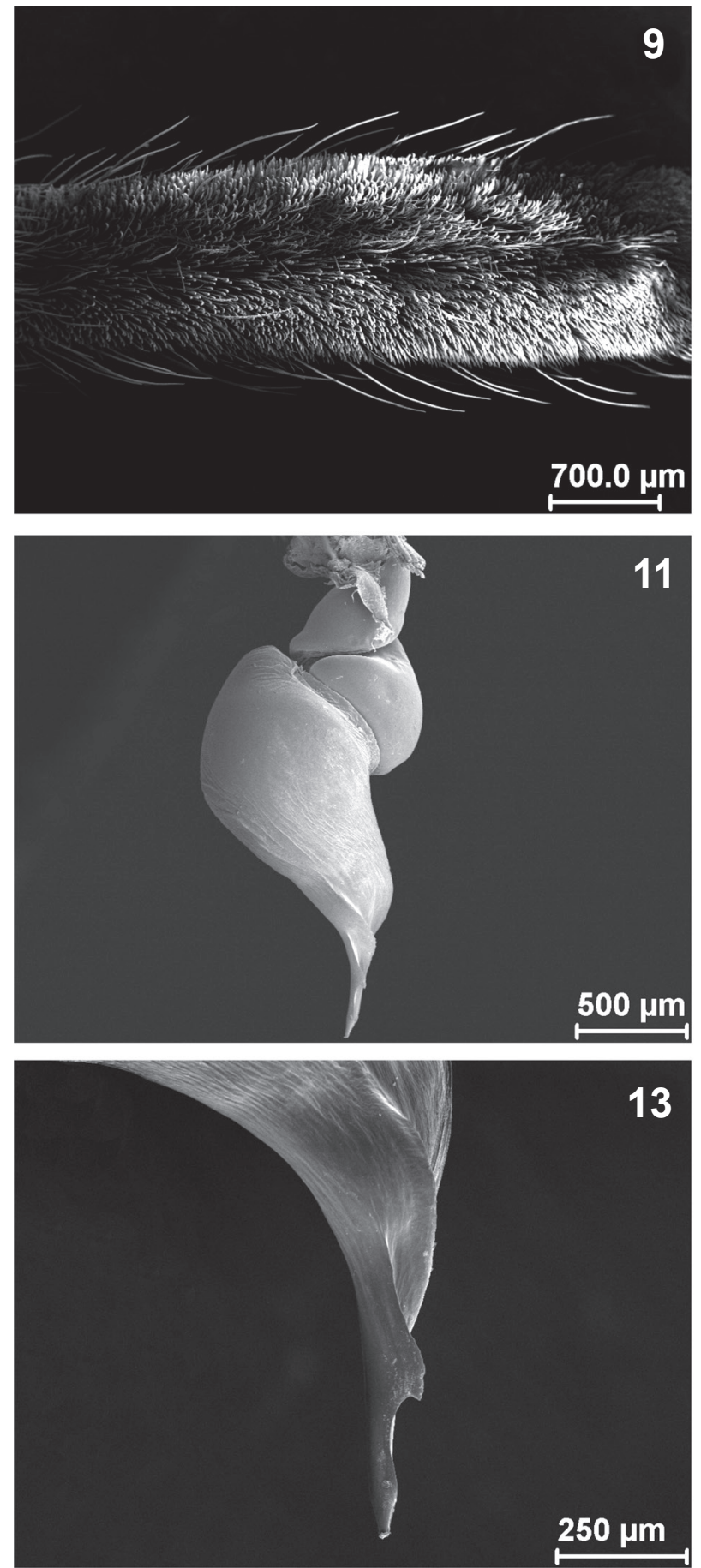

$5,14)$. Flexion of metatarsus I between both branches of tibial apophysis. Palpal organ piriform, PSK, PIK, lanceolate PAK present (Figs 6, 7, 11-13). Length of leg and palpal segments (Tab. I); femora III incrassate. Spination: femora I 1D; II 1D; III 1P, 1D; IV 1D; palp 1D. Patellae I-II 0; III 1P; IV 0; palp 1P. Tibiae I 2P, 2R,2V; II 5V, 1D; III 4P, 2R, 4V, 2D; IV 5P, 3R, 6V, 3D; palp 2P, 1V. Metatarsi I 1P, 4V; II 1P, 3V; III 4P, 4R, 4V, 2D; IV 5P, 3R, 6V, 3D; Tarsi I-IV and palp 0. Color: Cephalothorax (Fig. 1), legs reddish brown,
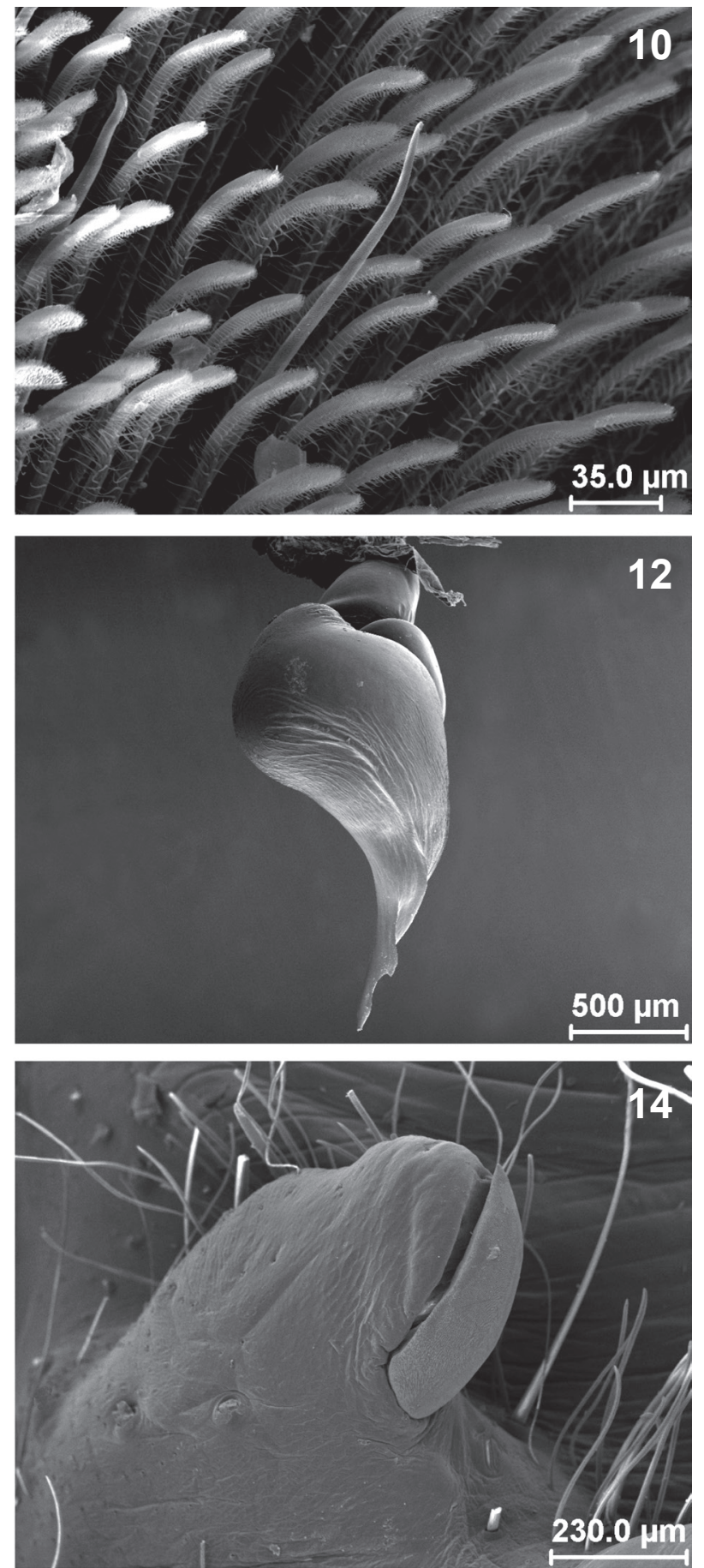

Figs 9-14. Munduruku bicoloratum gen. nov., sp. nov.: 9, 10, 14, male paratype (MPEG 19027): 9, 10, scopula, tarsi I, ventral; 14, spine in tibial apophysis. Male paratype (MPEG 19030), copulatory bulb: 11, prolateral; 12, prolateral, embolar apex flattened in $50^{\circ}$ angle; 13 , embolous, prolateral, embolar apex flattened in $50^{\circ}$ angle. 
Tab. I. Length of legs and palpal segments of holotype male/paratype female of Munduruku bicoloratum gen. nov., sp. nov.

\begin{tabular}{|c|c|c|c|c|c|}
\hline & $\mathrm{I}$ & II & III & IV & Palp \\
\hline Femora & $11.0 / 4.20$ & $10.30 / 4.30$ & $9.70 / 4.10$ & $13.50 / 5.30$ & $6.50 / 3.50$ \\
\hline Patellae & $6.80 / 3.30$ & $6.20 / 3.00$ & $4.80 / 2.30$ & $5.30 / 2.90$ & $3.80 / 2.30$ \\
\hline Tibiae & $7.80 / 3.90$ & $7.60 / 2.90$ & $6.30 / 2.50$ & $9.80 / 4.00$ & $5.00 / 2.20$ \\
\hline Metatarsi & $9.20 / 2.20$ & $9.20 / 2.80$ & $12.00 / 4.00$ & $15.90 / 5.80$ & - \\
\hline Tarsi & $4.80 / 1.60$ & $4.70 / 1.90$ & $5.00 / 2.10$ & $5.80 / 2.60$ & $1.80 / 2.30$ \\
\hline Total & $39.60 / 15.20$ & $38.00 / 14.90$ & $37.80 / 15.00$ & $50.30 / 20.60$ & $17.10 / 10.30$ \\
\hline
\end{tabular}

abdomen with dark brown wide dorsal chevron with lateral projections, sides, venter light brown (Fig. 2). Type III urticating hairs present. PMS well developed, PLS normal, apical segment digitiform.

Female (Paratype): total length (excluding chelicerae and spinnerets) 22.00. Cephalothorax length 8.63 , width 7.75. Anterior eye row procurved, posterior row recurved. Eye sizes and interdistances: AME 0.40, ALE 0.47, PME 0.12, PLE 0.28, AME-AME 0.20, AME-ALE 0.10, PME-PME 0.88, PME-PLE 0.06, ALE-PLE 0.18, OQ length 1.06, width 1.56, clypeus 0.44 . Fovea slightly procurved, width 1.28 . Labium length 1.22 , width 1.48 , with 92 cuspules, maxillae with 268 cuspules. Sternum length 3.75 , width 4.83 . Posterior sigillae submarginal. Chelicerae with $12 / 11$ teeth on promargin, group of $31 / 32$ smaller basal teeth, behind promarginal line. Tarsi densely scopulate, scopulae I-II divided by narrow stripe of longer conical setae; III-IV divided by band of longer conical setae. Metatarsi I-II scopulate on distal third, III scopulate on distal 1/5, IV without scopula. Length of leg and palpal segments (Tab. I). Spination: femora I 1P; II 1P; III 0; IV 0; palp 1P. Patellae I-II 0, III 1P; IV and palp 0. Tibiae I 0; II 0; III 1V; IV 1V; palp 3V. Metatarsi: I 3V; II 5V, 1P; III 3P, 2R, 6V; IV 2P, 3R, 7V. Tarsi I-IV and palp, 0 .

Color: as in male (Fig. 3). Type III, IV urticating hairs present. PMS slightly smaller than in male; PLS as in male. Spermathecae with two esferoid distal receptacles with funnel-shaped necks, spermathecal bases wide, sclerotized (Fig. 8).

Natural History. Most of the specimens from Canaã and Juruti were collected in pitfall traps used for herpetological survey. Some specimens from Juruti were collected by manual search at night (MPEG 19029) and from a project of wildlife rescue (MPEG 19030).
Acknowledgments. We greatly thank to MPEG's field teams of arachnologists (D. F. Candiani and N. C. Bastos) and herpetologists (A. Lima, A. J. Baia Goes, H. F. da Silva Filho, M. S. Hoogmoed, P. Suarez and T. C. S. Ávila-Pires) who collected the specimens studied in this paper. Alcoa Inc. supported the fieldwork. We would like to thank the referees for valuable suggestions and criticism. Also thanks to CNPq for the financial support (grants DOC\#143220/2009-8 to LTM, PQ\#304965/2012-0 to ABB and PV\#450468/2011-9 to FPM).

\section{REFERENCES}

Bertani, R. 2000. Male palpal bulbs and homologous features in Theraphosinae, (Araneae, Theraphosidae). Journal of Arachnology 28:29-42.

Cooke, J. A. L.; Roth, V. D. \& Miller, F. H. 1972. The urticating hairs of theraphosid spiders. American Museum Novitates 2498: $1-43$

MincH, E. W. 1989. Comments on the proposed presence of Aphonopelma Pocock, 1901 over Rechostica Simon, 1892 (Arachnida, Araneae). Bulletin of Zoological Nomenclature 46:189.

Perdomo, C.; Panzera, A. \& Pérez-Miles, F. 2009. Hapalopus aymara, a new species of tarantula from Bolivia (Araneae Theraphosidae, Theraphosinae). Iheringia, Série Zoologia 99(1):53-55

Pérez-Miles, F.; Lucas, S. M.; Silva, P. DA \& Bertani, R. 1996. Systematic revision and cladistic analysis of Theraphosinae (Araneae: Theraphosidae). Mygalomorph 1:33-62

Platnick, N. I. 1976. Are monotypic genera possible? Systematic Zoology 25:198-199

2013. The world spider catalog, version 12.5. American Museum of Natural History. Available at $<$ http://research.amnh. org/iz/spiders/catalog $>$. Accessed on 22 August 2012.

RAVEN, R. J. 1985. The spider infraorder Mygalomorphae (Araneae): Cladistics and systematics. Bulletin of the American Museum of Natural History 182:1-180.

1990. A revision of the Australian spider genus Trittame Koch (Mygalomorphae: Barychelidae) and a new related genus. Invertebrate Taxonomy 4:21-54.

Schiapelli, R. D. \& Gerschman, B. S. P. 1979. Las arañas de la subfamilia "Theraphosinae" (Araneae, Theraphosidae). Revista del Museo Argentino de Ciencias Naturales "Bernardino Rivadavia" 5:287-330.

VAlerio, C. E. 1980. Arañas terafósidas de Costa Rica (Araneae, Theraphosidae). I. Sericopelma y Brachypelma. Brenesia 18:259288. 